
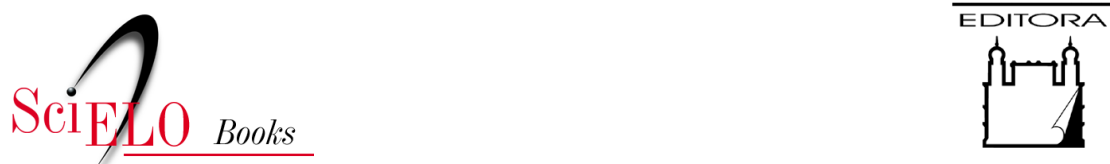

FIOCRUZ

\title{
5. "Pode esperar? Dá para aguentar?" a perspectiva dos seguranças, porteiros e recepcionistas
}

Armelle Giglio-Jacquemot

\section{SciELO Books / SciELO Livros / SciELO Libros}

GIGLIO-JACQUEMOT, A. "Pode esperar? Dá para aguentar?": a perspectiva dos seguranças, porteiros e recepcionistas. In:

Urgências e emergências em saúde: perspectivas de profissionais e usuários [online]. Rio de Janeiro: Editora FIOCRUZ, 2005, pp. 7598. Antropologia e Saúde collection. ISBN: 978-85-7541-378-4. https://doi.org/10.7476/9788575413784.0007.

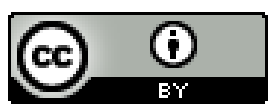

All the contents of this work, except where otherwise noted, is licensed under a Creative Commons Attribution 4.0 International license.

Todo o conteúdo deste trabalho, exceto quando houver ressalva, é publicado sob a licença Creative Commons Atribição 4.0.

Todo el contenido de esta obra, excepto donde se indique lo contrario, está bajo licencia de la licencia Creative Commons Reconocimento 4.0. 


\section{5 \\ "Pode Esperar? Dá para Agüentar?": a perspectiva dos seguranças, porteiros e recepcionistas}

O pessoal não médico do pronto-socorro mobiliza representações das urgências e das emergências que parecem, em diversos pontos, com as dos profissionais da saúde. Apresentam, porém, diferenças que, como as semelhanças, merecem ser apontadas.

\section{Os Seguranças e Porteiros}

Antes de trabalharem no pronto-socorro, os seguranças, empregados de uma empresa privada, trabalhavam em bancos e organizações públicas. Alguns, aliás, continuavam com esse primeiro emprego em seus dias de folga do pronto-socorro. Antes, nunca tinham atuado na área da saúde, portanto, essa primeira experiência os colocava diante de situações inéditas. Esse dado tem de ser levado em consideração na leitura do que vem a seguir, pois se os seguranças estivessem ocupando essa função há algum tempo - como é o caso dos porteiros e das recepcionistas - há de se pensar que os dados de observação e de discurso recolhidos a seu respeito poderiam ter sido diferentes. Por exemplo, o fato de eles se mostrarem muito sensibilizados pelo que acontece no pronto-socorro, e especialmente com os pacientes, pode estar ligado, não só à sua identificação com pessoas que pertencem à mesma camada social que eles, mas também ao fato de que são novos no emprego.

Acostumados com o universo do pronto-socorro, as recepcionistas e os porteiros também apresentam o mesmo perfil sociológico dos pacientes, porém mostram-se indiferentes a muitas situações que tocam os seguranças. Quando comecei o trabalho de campo, estes estavam descobrindo uma realidade que, mesmo se não a desconhecessem por já terem ido como pacientes ou acompanhantes a um pronto-socorro, não conheciam a partir do lugar e da função de segurança.

\section{InCONFORMADOS E Críticos}

Ficando $12 \mathrm{~h}$ seguidas em pé, ${ }^{1}$ na entrada ou na sala de espera, os guardas encontram-se como observadores de uma multidão de situações que os deixam muito críticos em relação ao que acontece no pronto-socorro e, especialmente, em relação ao 
comportamento dos médicos. Expressam sua indignação, no tom da confidência, contando-me espontaneamente as coisas que os revoltam. No início, alguns deles chegaram até a dizer que não iam ficar por muito tempo nesse emprego.

Eis alguns trechos de conversa representativos de seus comentários críticos $\mathrm{e}$ que testemunham sua sensibilidade à situação dos pacientes, até sua empatia:

O segurança é surdo e mudo. Mas se eu contar tudo que vejo aqui, teria bombas para muitos. Coisas erradas e coisas certas, você vai ver aqui, mas você vai ver sobretudo coisas erradas. Aqui é um absurdo. [E, depois de ter contado a história de um menino que, segundo ele, morreu no pronto-socorro, por falta de cuidados:] A pessoa fica quieta, não diz nada, os médicos não prestam atenção. [E, no tom da ameaça: 7 Se eu levar minha mulher ou meu filho e tratarem desse jeito! (...) O outro dia, minha mulher levou a menina da vizinha que tinha cortado o pé, desceram para o raio- $X$, esperaram uma meia hora lá em baixo, o médico estava assistindo $O$ Ratinho! (...) Eles [os médicos] atendem rápido só quem vem de ambulância ou de bombeiros. Os outros ficam sentados, que nem essa mulher que desmaiou. Se a cabeça dela bater nos ferros ou no chão, você imagina... Segurei a cabeça nas minhas mâos. Ela se queixava de dor, chorava, mas não ligaram para ela, até ela cair.

O segurança tem que ser mentiroso, cego, mudo e surdo. (...) É um trabalho dificil, você vê tantas coisas e não diz nada, nós vemos tudo que acontece aqui. Eles [os médicos] nem olham na sala de espera. [Conclui que é mais fácil e tranquillo ser segurança de bancol.

O médico diz que nós temos dó demais deles [os pacientes], que têm que ser rígidos, que não pode ter o coração mole. Dizem que os pacientes mentem, mas eu tenho dó, não sou assim. Se eu ver que uma pessoa está passando mal, eu coloco ela dentro [da área de atendimento]. Se o médico achar nim, pego o nome dele e se tiver qualquer problema, digo que não quis atender. Felizmente essa situação nunca aconteceu.

Os médicos dizem para nós que os pacientes fingem, que a gente não deve se sensibilizar, talvez seja verdade para alguns deles, mas para a maioria está errado. Tenho dó. A gente ol ha para as pessoas e não pode fazer nada. É como essa menina que está chorando, o que quê ela tem? [Depois de alguns minutos, vai falar com ela e volta dizendo:] - É a garganta, muito vermelha, inchada. [E repete várias vezes: $]$ - Deve sentir muita dor.

[Comentando a atitude de uma médica:] Que frieza, estudar tanto para isso! E não é porque a pessoa entra dentro [da área de atendinento] que eles [os médicos] cuidam dela, eles deixam ela num cantinho, numa maca, eles ie deixam sem cuidados (...) Isso é nosso [o PS], isso é público. Mas mesmo assim somos bem mal tratados.

Entretanto, os seguranças não deixaram o emprego. Mas o discurso foi mudando. Menos revoltados e mais acomodados ao longo das semanas, continuaram achando que o que acontece no pronto-socorro "não está certo", mas mostravam mais distância e tranqüilidade: "aqui é bem pesado, mas já me acostumei"; "tenho dó, mas agora 
me acostumei". Até o mais inconformado no início, acabou achando seu trabalho "gostoso" e explicava: "me ajuda a tomar distância, agora vejo um caso grave, uma coisa absurda, eu dou risada. Esse trabalho é uma terapia".

Somente um deles, um dia, não apareceu mais no pronto-socorro e passou a trabalhar no portão de uma outra entrada do hospital. Foi transferido de lugar porque, segundo suas próprias palavras, os médicos e o chefe da segurança o achavam "demais emotivo". "Uma médica me disse que eu era demais sentimental", comentou ele, lamentando ter precisado deixar esse trabalho porque "gostava de ajudar" apesar de que "no pronto-socorro, muita gente tem o coração ruim, sobretudo os médicos". Alegou ter presenciado vários comportamentos "errados" por parte da equipe médica e, entre eles, relatou o caso de dois pacientes "que [os médicos] deixaram na espera" "um com hemorragia" e um outro "que desmaiou" - e que, sem autorização dos médicos, ele levou para a área de atendimento, iniciativas que certamente estavam na origem de sua saída do pronto-socorro: "desmaio, hemorragia, tem que entrar direto!" exclamou indignado, acrescentando que não estava com vontade de se tornar "insensível" e que "se tiver que perder o emprego vou perder, mas não vou mudar".

As críticas dos guardas mostram claramente que suas representações do urgente, suas apreciações do que "pode esperar" e do que necessita de um atendimento rápido, entram em conflito com o que o cotidiano do pronto-socorro revela das práticas dos profissionais em relação à urgência. Porém, a manifestação desse confronto por parte deles não passa, geralmente, de severos, mas discretos, julgamentos, e fica imperceptível ao observador exterior.

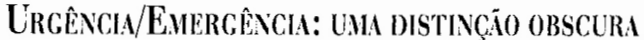

Talvez por serem novos no pronto-socorro, mas não necessariamente, os seguranças não têm nenhuma familiaridade com a discriminação entre urgência e emergência. Apesar de sua função os levarem a recorrer a essa distinção e terminologia com freqüência - "toco duas vezes na campainha no caso de uma emergência", "aqui é só urgência-emergência" - as diferenças entre as duas categorias de urgência como seu significado próprio não é nada claro para eles. Nisso, não diferem dos usuários.

$\mathrm{Se}$, de um lado, entendem que certas urgências são mais graves do que outras, do outro lado, não sabem muito bem às quais se aplicam os termos 'urgência' e 'emergência'. Às vezes, apresentam as urgências como sendo mais graves do que as emergências, mas também dizem o contrário; às vezes, as urgências e as emergências são tudo que chega no pronto-socorro, é tudo igual e 'urgência emergência' se torna uma palavra só. Às vezes, é o próprio meio de transporte que traz o paciente que determina se é urgência (ambulância) ou emergência (bombeiro), sem que o critério de gravidade seja levado em conta na distinção entre as duas, assim como mostram esses trechos de suas falas: "Um toque [de campainha] é quando é uma emergência não muito grave; dois toques é quando vem o Resgate, você já sabe"; "Campainha é urgência. 1 toque: menos grave. 2 toques: mais grave"; "Dois toques é quando é uma urgência, quando é grave"; "Dois toques é quando é urgência emergência"; "Emergência é bombeiro, dois toques; urgência são as ambulâncias, um toque"; "Se tivesse só urgência 
emergência aqui, não teria tantas pessoas"; "Urgência emergência, acho que é a mesma coisa. Que nem esse cara. Pode esperar"; "A emergência é todos que vềm aí... $A$ urgência é quando está ruim, quando está nas últimas"; "Urgência tem que intervir rápido (...), emergência são essas pessoas [os pacientes esperando]"; "o que ela tem demora para curar, o tratamento é demorado, não é agora que ela vai melhorar, não é urgente" (Grifos meus).

Apesar de terem uma compreensão variável do que são uma urgência e uma emergência, os seguranças não deixam de ter uma apreciação do que é grave, quer eles chamem isso 'urgência', 'emergência' ou ainda 'urgência emergência'. E, apesar de não ser sua função declarada, eles observam os pacientes com atenção, preocupados em presenciar os indicios de um possível caso grave.

\section{Observação Atenta e Sentimento de Responsabulidade}

Entre todos os profissionais do pronto-socorro, os seguranças são os únicos, com os porteiros, que vêem o que acontece na sala de espera adulto. A pequena sala onde se encontram as recepcionistas não dá visão para as salas de espera (adulto, infantil), mas para uma parede e um relógio, ${ }^{2}$ e quando saem desse iugar para entregarem as fichas nas áreas de atendimento, elas atravessam rapidamente os espaços reservados ao público sem olhar para ele. No que diz respeito aos profissionais de saúde, já vimos que eles geralmente não vão para as salas de espera, e quando as atravessam é também de maneira apressada. "Os médicos passam correndo pela sala de espera", "os médicos nunca estão por lá", observam os seguranças. Aliás, discursos de médicos confirmam o que a própria observação leva a pensar, a saber, que sua ausência nas salas de espera e a rapidez de sua passagem por elas são voluntárias. "Năo fico fora, não vou na sala de espera", diz esse médico (responsável pela triagem clínica do pronto-socorro infantil) que explica os motivos de sua atitude da seguinte maneira:

Se olhasse para eles, se passasse no meio deles na sala de espera, daria para ver quem tem que ser atendido, mas não faço, não posso, nenhum dos médicos do pronto-socorro faz. Eu passo, dou uma olhada mas não mais, não olho para eles. Se eu olhar vão achar que estou dando risada, não dá para passar entre eles, eles vão achar que não faço nada. Eles vão me falar, não vou poder trabalhar mais.

Os únicos observadores da sala de espera do pronto-socorro adulto ${ }^{3}$ são, então, os seguranças e porteiros: é a eles que está abandonada essa tarefa que, aliás, levam muito a sério. Intriga constatar o quanto, apesar de não terem nenhuma formação médica e não estarem explicitamente encarregados da triagem médica dos pacientes, eles desempenham sua tarefa de observação não só com aplicação, mas também com o sentimento de serem responsáveis por tudo que acontece na sala de espera, inclusive pelo estado de saúde das pessoas que estão aguardando. Os seguranças e porteiros vivem a eventualidade temida de um paciente passar mal - desmaiar, por exemplo como uma coisa a ser absolutamente evitada. Interiorizaram que é de sua responsabilidade impedir esse tipo de situação, como se dependesse deles, de sua competência ou incompetência, acontecer ou não: "a gente tem que se proteger no caso de problemas, 
[diz esse guarda da entrada], pois tudo que acontece na sala de espera é problema nosso, é da nossa responsabilidade. É o que dizem os médicos para nós".

Não deu para saber com certeza se este sentimento é o resultado da incorporação pelos seguranças e porteiros de uma responsabilidade que os profissionais de saúde passam para eles, de maneira implícita ou explícita, ou se são eles mesmos que fazem uma interpretação exagerada de sua função de segurança, ou se é, ainda, uma mistura dos dois. Mas, com efeito, eles são encarregados de avisar um médico na área de atendimento quando presenciam que "uma pessoa está passando mal", e essa atribuição pode estar na origem de seu sentimento de responsabilidade. O fato é que eles se consideram responsáveis pelos pacientes que aguardam, e mais do que os próprios profissionais de saúde que lhes deixam a tarefa de olhá-los atenciosamente para poder intervir a tempo, caso precisar. Dai a seriedade e a preocupação com as quais desempenham seu papel de vigia.

A contrapartida valorizante é o orgulho que os seguranças têm por sua habilidade em ver e perceber "as coisas". Contando-me uma história de ladrões que tinha reparado na rodoviária, um dos guardas declarou possuir um talento especial para "sentir essas coisas": "é como no PS, eu olho, olho, olho e vejo quando a pessoa não vai bem ou está passando mal". Aliás, os médicos já lhe disseram que "para isso, tenho nota 10 " e que ele é "muito bom para ver quem fica doente ou quem vai passar mal, para ver os pacientes que precisam: eu vejo quando a pessoa tem falta de ar e vai cair no chão", diz ele, exemplificando com o caso de uma mulher que tinha desmaiado alguns dias atrás na sala de espera (situação que também presenciei). Ele foi o primeiro, entre os seguranças e porteiros, a reparar que ela ia desmaiar e, por isso, precipitou-se para "pegar a cabeça da mulher" antes de ela cair, para "a cabeça não bater no chão" "Ela era muito gorda, então imagina com todo esse peso, a cabeça bater no chão, pode se matar", comentou ele.

Um dos porteiros do hospital, o mais antigo nessa função, procura se distinguir dos seguranças justamente por sua aptidão aguçada em reconhecer "quem está passando mal". Afirma sua competência na leitura dos sinais de gravidade, negando a dos guardas: "não sabem", "erram", "não servem para trabalhar, não têm preparo", diz a respeito deles. Sente-se muito importante, e até indispensável, por ter essa faculdade e declara com muito orgulho: "os médicos nunca vão me tirar do lugar". Aliás, ele sempre insistiu, em nossas conversas, em dizer o quanto os médicos o acham competente.

Cada segurança e porteiro, tendo interiorizado que o segurança ou o porteiro 'bom' é esse que 'sabe ver', pressentir, 'reconhecer' o que é grave ou que pode vir a se tornar como tal, faz existir, entre eles, uma competição que se expressa no campo da competência em ler os sinais de urgência. Os pacientes se tornam, às vezes, vítimas dessa rivalidade na medida em que são objetos de ordens contraditórias. É o que aconteceu, por exemplo, a um homem de uns 50 anos que chegou em pé no prontosocorro, mancando e com sangue seco no rosto e na calça rasgada. Quando passou a porta de entrada, o primeiro segurança pediu para ele tirar o chapéu: o homem tinha os cabelos cheios de sangue e uma ferida no crânio. Vendo isso, o segurança o mandou direto para área de atendimento médico e falou que faria sua ficha depois. Para ele, então, esse paciente não podia esperar: o que tinha podia ser alguma coisa grave, assim 
comentou comigo. Quando o homem chegou na frente da porta da área de atendimento adulto e tentou entrar, o porteiro ${ }^{4}$ que fica nesse lugar também pediu para ele tirar o chapéu. Olhou para a cabeça e mandou o homem entrar na fila para preencher sua ficha. Achou que ele podia esperar. Como o homem falou que o segurança da entrada tinha dito para ele entrar direto, o porteiro respondeu com autoridade que não era o caso e voltou a lhe indicar a recepção com um dedo firme, direção que o homem seguiu sem insistir.

Numerosas são as situações em que um guarda se acha mais competente na leitura dos sinais de gravidade do que um outro. Aliás, em última instância, é sempre o que fica na porta da área de atendimento adulto que impõe seu ponto de vista e sua autoridade. Pois é ele que libera, ou não, a entrada do paciente. Presenciei uma situação em que o porteiro da entrada da área de atendimento até ameaçou os seguranças - que tinham aberto a porta no seu lugar para fazer entrar um doente que achavam urgente de botar o paciente fora "caso não for grave".

\section{Os Sinais}

O que alerta esses observadores da sala de espera do pronto-socorro? Quais são os sinais por eles levados a sério? De uma maneira geral, são os mesmos que foram apontados para os profissionais da saúde, porém com diferenças e divergências significativas. Assim, ao contrário do que foi observado com os médicos, as manifestações de sofrimento e de medo têm um alto valor mobilizador para os seguranças que as encaram como indícios de possíveis urgências. Ficam de olho nos pacientes que expressam esse tipo de manifestações e é geralmente para estes que chamam a atenção dos médicos. Para eles, quem está com muita dor não pode esperar; é o que indicam não tanto seus discursos quanto seus comportamentos. Tentam apressar o atendimento dos pacientes que sofrem (especialmente quando se trata de mulheres e crianças) indo primeiro falar com um médico ou um enfermeiro dentro da área de atendimento, ou colocando o paciente direto dentro da área.

Já foi assinalada a preocupação especial de certos guardas com as pessoas se queixando de cólicas renais. Entre as várias situações nas quais presenciei sua importância, teve uma em que um segurança chamou a atenção do médico-chefe do prontosocorro para uma moça que estava de cócoras, encostada na parede e manifestando muita dor. "Ela está com cólica renal", falou para mim antes de ir à procura do médico que a atendeu em seguida. Mas o segurança teve de justificar sua atitude, pois o filho de um outro paciente, sentado em uma cadeira de rodas, reclamou dizendo que estava esperando a vez de seu pai há horas. O guarda lhe explicou que as dores da cólica renal são "horríveis". O argumento do sofrimento insuportável aparentemente convenceu o filho de que o caso da moça era mais urgente, pois concordou dizendo que, de toda maneira, no caso de seu pai "não tem cura": "está com a doença de chagas" da qual se morre, então "não tem pressa".

De maneira geral, os seguranças são atentos à aparência física e aos comportamentos dos pacientes, assim como às expressões de seu rosto, isto é, a tudo o que ele oferece a ver e a ler: cor, lágrimas, respiração difícil, sangue, dor, medo, pavor, fraqueza etc.: 
[tinha] uma mulher esperando aqui, gritando o tempo todo, estava ol hando para ela fazia tempo, de repente parou de gritar. É nesse momento que voltei a olhar para ela, os olhos se fechavam, sabe assim os olhos se fecham, eu vi o momento dela cair, ela começou a cair, chamei o outro segurança, o médico pegou ela. segurei a cabeça dela para não cair no chão, foi levada para dentro.

Vi que estava mal porque a carteira dela caiu no châo e não pegou. Fui ver ela, ela disse que não sabe o que está acontecendo com ela, mas que tem um problema na vista e não vê mais nada. Peguei ela para levar para dentro, mas começou a cair. Segurei a cabeça para não bater no chão.

Você olha, se o paciente estiver ensangüentado, é emergência.

Não tinha dito? Ele chegou morto. Parada cardiaca. O cara está tudo roxo e você viu o sangue que saia da boca?

Faz quarenta dias que trabalho aqui: já vi cinco mortos, três paradas cardiacas e dois esfaqueados. Sei quem é morto já na porta de entrada porque quem tem parada cardiaca é roxo.

Eu olho, eu vejo, se a criança não está acordada, se não estiver..., levo correndo para o PS infantil; isso não significa que se a criança estiver acordada não necessita atendimento, mas aí já não é aquela correria.

Quando o cara chega apavorado, descendo rápido do carro, vocêjá sabe que é emergência.

Estranho, sentada ela parecia bem, e ela parece ruim agora. Não vi.

Você vê esse moço, está com 17 anos. É muito magro, não sei o que ele tem... Aids...

Se os seguranças procuram, no rosto e nos comportamentos dos pacientes, os indícios de uma possível gravidade, eles também se baseiam no que dizem e, neste aspecto, ainda se distinguem dos médicos:

A amiga dela disse para mim que era aborto, que estava sangrando, eu disse:psssittt! Entre direto! Disse que está grávida de cinco meses! ${ }^{5}$

[Uma mãe entra na sala de espera segurando uma menina que parece muito fraca. O segurança vai atrás dela e lhe pergunta]: - O que aconteceu com a menina? - A pressão dela caiu muito, está para baixo, [responde a mãe]. [O segurança]: - Essa entra direto. Qual a idade dela? - I0 anos. [Indica para a mãe a entrada da área de atendimento infantil]

Os pacientes que se queixam de muita dor, de pressão alta ou baixa, de falta de ar, de dor no braço e no peito, assim como as mulheres grávidas que dizem estar com dor, chamam a atenção dos guardas. "As grávidas, as cólicas renais e as crises 
broncopulmonares, acho que esses têm que entrar direto. Quem está com dor no peito, no braço e falta de ar, também. Enfarte", fala um segurança. E para provar que ele está certo, relata-me em seguida uma discussão que teve com uma enfermeira por ter colocado direto na sala de emergência uma mulher que estava na espera. Diz ter tomado essa iniciativa porque, na conversa que teve com a paciente na sala de espera - foi conversar com ela, pois "vi que não estava bem" - ela se queixou de dor no peito e de falta de ar: "isso é enfarte !". Quando a enfermeira viu a paciente na sala de emergência, repreendeu o guarda e mandou a mulher aguardar fora. "Pode esperar, é crise convulsiva, não é enfarte", ela teria afirmado. E a paciente morreu porque, afinal, era um enfarte.

Esse exemplo não somente mostra a importância conferida pelos seguranças a certos sintomas e a atenção que dão à queixa dos pacientes. Indica também uma outra constatação: o fato de deixar aos seguranças um papel tão ativo, importante e primeiro na triagem médica, ${ }^{7}$ acaba desembocando, de vez em quando, em conflitos de competências com os profissionais da saúde (o que também acontece, pelas mesmas razões, com as recepcionistas, como será visto a seguir). A responsabilidade e o papel atribuídos aos seguranças na sala de espera se traduz, em certas ocasiões, pela contestação da apreciação médica: eles acham que sabem melhor da gravidade do estado dos pacientes - que observam e com quem conversam - do que os que "nem olham para eles". Daí também o julgamento severo - "está errado", "não está certo" - em relação ao que vêem no pronto-socorro, especialmente por parte da equipe médica.

Voltando à exposição dos sinais levados a sério pelos guardas, constata-se que qualquer problema que envolve a cabeça, ou que está nela localizado, também tende a ser considerado como urgente, quer seja manifesto (corte, sangue, inconsciência) ou não (o paciente se queixa de um problema nessa região do corpo: bateu a cabeça, está com muita dor de cabeça, tem problema na vista...). Várias citações já mostraram o quanto "a cabeça" é presente nos seus relatos de casos graves, e especialmente nos de desmaio, sinal de urgência por excelência: "não pode bater a cabeça", "segurei a cabeça para não bater", "qualquer pancada na cabeça é urgência, mesmo que não sangre" etc. A cabeça é a parte do corpo objeto da maior atenção e das suspeitas mais sistemáticas $\mathrm{em}$ termo de gravidade. Tudo que lhe ocorre diretamente (choque, corte, dor) ou que afeta o que é concebido como dependendo dela (consciência, vista) é tido como potencialmente grave. A cabeça tem de ser preservada, imediatamente cuidada: não há pequenos problemas entre os diversos que acontecem com ela.

Da mesma maneira, qualquer pessoa que está com sangue, não só na cabeça, mas em qualquer região do corpo, alerta os seguranças e mobiliza sua atenção, quer sua aparência seja ou não impressionante em termos de ferimento visivel, quer seu sangue esteja seco ou que ela esteja sangrando. Muitas vezes procuram apressar o atendimento desses pacientes. $O$ mesmo acontece com as pessoas que não parecem firmes na maneira de andar ou de ficar sentadas.

\section{A Confiança nos Pacientes}

Dito isso, o mais interessante não é tanto insistir na enumeração dos sinais que suscitam a mobilização dos guardas quanto sublinhar que se baseiam no que os pacientes 
dão a ver e dizem: acreditam em seus comportamentos e falas. A escolha do verbo 'acreditar' não é fortuita, pois, o que talvez mais impressione em inúmeras atitudes e falas de médicos e enfermeiras é sua desconfiança nos pacientes. Apresentados e considerados 'ignorantes', 'mentirosos', 'atores', 'preguiçosos', 'fracos', 'espertinhos', que tentam enganar os médicos ou se aproveitar do pronto-socorro para satisfazer necessidades não médicas, ${ }^{8}$ suas queixas, falas e atitudes são suspeitas de falsidade, por ignorância ou por fingimento. Pelo crédito que dão aos pacientes, os seguranças se distinguem nitidamente do conjunto dos profissionais que atuam no pronto-socorro.

Os porteiros, funcionários já antigos do hospital, compartilham e expressam a mesma desconfiança que os profissionais de saúde (as recepcionistas também). Suas falas a respeito dos pacientes são a reprodução do discurso dos médicos. Na perspectiva desses profissionais, apreendida através de suas críticas ao trabalho dos seguranças, suspeitar dos pacientes é uma marca de experiência. Os trechos seguintes de uma conversa que tive com um deles são bem representativos dessa visão, ao mesmo tempo desconfiada e depreciativa, dos pacientes:

Você acabou de pronunciar uma palavra importante: desmaio. É uma das coisas mais importantes que temos que saber reconhecer. Desmaio pode ser emergência, pode ser enfarte, pode ser derrame. O verdadeiro, não o fingido. É importante saber [reconhecer um do outro] para evitar o desgaste do corpo. Em vez de você ter que carregar a pessoa, colocar ela numa maca, ela entra em pé. [Explica que se sabe quando o desmaio está fingindo porque 'os cilios vibram'. E que quando a pessoa está desmaiada 'de verdade', se levantar o braço dela acima da cabeça e deixar tombar, ele cai em seu rosto. Enquanto quem finge, que nem 'o psicótico', guarda o braço erguido ou larga no ombro]. Você sabe como fazem os médicos para saber? Eles torcem o mamilo da pessoa, seja homem ou mulher. Já vi, a pessoa desmaiada de verdade, ela não sente nada.

E mais adiante, na conversa:

Não tem ninguém na sexta porque é final de semana, é diversão. O sábado e o domingo é só urgência. Na segunda, o pronto-socorro enche. O cara bebe ofinal de semana todo, enche a cara, perde a hora do serviço e vai para o prontosocorro para conseguir um atestado médico. Ou está se sentindo mal porque bebeu o final de semana todo (...). O problema é a falta de informação. O povo não sabe. Qualquer dor para eles é urgente. O PS é para vir quando você precisa de um exame aprofundado, uma tomografia, um raio- $X$, senão você vai para o posto de saúde. Mas eles não querem levantar às seis da manhã para marcar uma consulta, então vêm aqui e não podemos recusar eles. (...) Quando eu era moleque, não se ia no médico. Morava num sitio, minha mãe dava remédios caseiros. Tenho duas cicatrizes, uma é plástico quente que caiu no pé, não fui no médico. Hoje, o cara tem um cortinho na mão, já vem aqui! (...) Eles dizem 'passei mal, passei mal', para eles 'passar mal'é ter uma dor, uma dorzinha, na perna, na barriga e eles dizem que passam mal! Eu passo mal quando tenho uma diarréia, uma dor de cabeça forte. Tem pessoas que vêm aqui para uma dor de cabeça que já têm desde uma semana!" 


\section{Preconchtos e Discrimichäo}

Dois tipos de pacientes não suscitam muito dó por parte dos seguranças, bem ao contrário. Pelos que chamam de 'drogados' e 'bêbados' ${ }^{10}$ sentem desprezo e, com eles, seus comportamentos são bem diferentes. Segundo as circunstâncias, ficam rudes, agressivos ou totalmente indiferentes. Também zombam deles com usuários, médicos, enfermeiros cuja cumplicidade, nesses momentos, se assenta nos mesmos preconceitos, amplamente compartilhados. Apesar desses pacientes serem, muitas vezes, coletivamente ignorados, a ponto de parecerem invisíveis na sala de espera do prontosocorro, ${ }^{11}$ eles não deixam de ser discretamente observados pelos seguranças. Porém, não é porque seu estado é considerado como possivelmente urgente, ou podendo vir a se tornar sério. Os guardas estão atentos a eles para reprimir, a tempo, possíveis comportamentos julgados não desejáveis, perturbadores, ou ainda perigosos para os pacientes e o pessoal do pronto-socorro.

Os 'bêbados' e 'drogados' caem fora da categoria dos 'pacientes' e, por consequiência, das categorias da 'urgência' e da 'emergência', pois os seguranças acham que não são doentes na medida em que o estado no qual se encontram, mesmo que ruim, mesmo que grave, é o resultado do que chamam "uma escolha", em outros termos, estão assim porque "querem". São viciados e vício não é doença. Eles só atrapalham o atendimento das outras pessoas que, por serem consideradas 'pacientes', merecem atenção e cuidado. Assim, é comum ouvir, por parte dos seguranças, frases como: "paciente eu respeito. Agora bêbado e drogado, se encarar, apanha" ou, ainda, "vim aqui para trabalhar... e tenho que cuidar de bêbados! E tanta gente aqui, morrendo!". As raras vezes que observei guardas barrando a entrada do pronto-socorro a usuários querendo consultar, tratava-se sempre de pessoas alcoolizadas. São também esses pacientes que, muitas vezes, são amarrados em uma maca no meio da sala de espera e deixados assim, no chão e na frente de todo mundo, até serem atendidos. ${ }^{12}$ Os comentários e as reações das pessoas que passaram por essa situação mostram o quanto viveram-na como humilhante.

A desconsideração pelos 'bêbados' evidencia-se nas falas dos seguranças, em seus comportamentos e também nas situações nas quais estão envolvidos. Eis alguns casos representativos não somente de suas atitudes e reações com esse tipo de paciente, mas também do consenso geral no qual elas se inserem:

Caso 1: Um homem de 50 anos chega ao pronto-socorro transportado por uma ambulância do 192. Está alcoolizado e foi encontrado deitado na rua. Desce da ambulância ajudado pelo motorista que o deixa na sala de espera. Vai andando, em equilibrio muito precário, até uma cadeira onde se senta e põe sua cabeça nos joelhos, cercada pelos braços. E fica lá, sem que ninguém desse a impressão de ter notado sua presença. Depois de quinze minutos, levanta. andando como se fosse cair a cada passo, na indiferença geral. Dirige-se à saída, perde o equilíbrio c vai bater várias vezes contra a porta de entrada. Passa ao lado do segurança que não parece vê-lo, e começa a descer a rampa de acesso, cambaleando. Tensa com a situação. pergunto para o segurança da entrada, com quem estou justamente conversando. se não pensa que o homem precisa de ajuda. Só nesse momento parece perceber sua existência e responde, com indiferença: "é um 
bêbado". Olha para o homem que continua descendo sem firmeza, até o momento em que cai e fica deitado no chão, na calçada que beira a rampa de acesso. Aí, o segurança vira a cabeça na direção oposta e volta a falar comigo sobre coisas que não têm nada a ver com a cena. Como expresso, de maneira insistente, minha preocupação com o homem, agora imóvel no chão, o segurança entra na sala de espera e volta dizendo que avisou alguém. Mas, depois, parece se esquecer dele e ninguém - paciente, acompanhante. funcionário, profissional de saúde - saiu do pronto-socorro para dar uma olhada naquele homem, para leválo de volta à sala de espera, para atendê-lo. Ficou horas deitado na calçada do pronto-socorro, sem receber a mínima atenção, transparente ao mundo que se movimentava em redor dele.

CAso 2: Chega uma ambulância do 192. Através do pára-brisa, o motorista faz o gesto de beber para o segurança da porta de entrada. Assinala, dessa maneira. que está levando um paciente alcoolizado e que precisa de auxílio para tirá-lo da ambulância. O segurança resmunga, mas vai ajudá-lo a acordar a pessoa c levá-la para dentro da sala de espera. Aí, o motorista bota o paciente em uma maca. Fste diz. que não quer, com insistência, tenta levantar, mas não consegue, e fica. Voltando para a ambulância, o motorista fala para o segurança descontente: "não tem jeito, estou obrigado a pegar, senão é omissĩo de socorro". F, vai embora. Uma pessoa na espera fora, que presenciou a cena toda, fala para o segurança: "F́ segunda!".

Caso 3: Um paciente está sendo contido violentamente. Segundo um enfermeiro, ele está em coma alcoólico. Os enfermeiros o xingam e pisam em seu peito e em seu pescoço. Amarram seus pés e mãos, e quando falta apenas o peito. e portanto não há como o homem se soltar, um dos enfermeiros se utiliza de um lençol. pondo-o embolado no rosto do homem, como se simulasse uma tentativa de asfixiá-lo. Os enfermeiros riem e se divertem. Os seguranças também. Logo depois, conversando com um dos seguranças, obtenho a segunte fala: "esse aí é freguês antigo: se deixar, quebra tudo; geralmente são os enfermeiros [que o contêm]". A cena acontece na sala de espera do pronto-socorro adulto, ao lado do pilar. E o homem lica lá amarrado. Os outros pacientes viram a cena, e poucos tiveram reação. Futuramente, viria a saber por um segurança que a intenção do enfermeiro ao pôr o lençol no rosto de quem é contido é justamente, através do medo de ser sufocado, conseguir acalmar a pessoa. Algumas semanas depois, um guarda vem me perguntar se eu ponho no meu relatório os casos onde os pacientes são "maltratados". Uso como exemplo o caso do homem que foi contido com violência, então a conversa prossegue, cele me relata um outro caso. Um paciente muito nervoso estava sendo contido "de forma errada" pelos enfermeiros, um médico presenciou e os repreendeu. $\Lambda$ ssim que ficaram sós com o paciente, colocaram um lençol $\mathrm{cm}$ seu rosto para que pudessem aplicar a injeção. Segundo o segurança, é para "dar medo". Assin sendo, tal procedimento se mostra muito "eficiente", porque amedronta a pessoa que mesmo "amarrada corretamente" ainda tem movimentos que dificultam a aplicaçào. O guarda deve ter achado a cena muito humilhante, pois acabou concluindo: "deu uma dó". O cara olhou para o enfermeiro com mágoa! Imagina vecẻ amarrado com pano no rosto! 
CASo 4: X, encarregado de passar ordens para os seguranças, vem pedir que impeçam a entrada de duas pessoas especificas no pronto-socorro. Ao perceber minha presença, enfatiza: "só se vier machucado; isso é respeito com as pessoas que estão aí". Passados alguns minutos, quando $\mathrm{X}$ ainda se encontra na porta, apresenta-se uma das duas pessoas proibidas de entrar. É um homem, com aparência de andarilho e alcoolizado, que chega dizendo que quer "ver o médico". Impedido pelos seguranças de entrar e fazer sua ficha, o homem senta-se ao lado da porta, do lado de fora, e começa a resmungar dizendo que tem direitos. Vem então à porta um médico que dá uma breve olhada no homem, e comenta: "quer fazer ficha na psiquiatria; internação". E vai embora. Um paciente na espera que presenciou a cena exclama: "nossa, que milagre! Um doutor veio aqui ver o paciente!". Mas como depois dessa brevíssima consulta, o homem continua barrado, entendo que o médico deve ter julgado que o caso dele não é do pronto-socorro. Aparentemente livrado da responsabilidade de barrar esse paciente, o segurança comenta: "o médico olhou, ele sabe". Pergunto-lhe se o homem não tem direito a um atendimento, e ele responde: "bêbado assim não; ele quer ser internado". Um outro guarda acrescenta para mim: "sabe qual é a instrução para os seguranças de azul [de empresa]? Para cara pingaiado que encher o saco, dá borrachada no coco". Entendo também algumas frases do homem barrado que fala: "se eu vim aqui, é porque eu preciso, sinto fraqueza, tremedeira, hospital tem que atender". Contrastando com a opinião do primeiro segurança, um porteiro me diz discretamente que não acha certo tal procedimento, que se deveria pelo menos deixar o homem entrar, para então explicarlhe que a internação não será feita. Vou falar com o médico que olhou o homem e pergunto se este não tem direito de ser atendido. Responde-me que apenas aguarda a chegada do médico psiquiatra, para em seguida chamar o homem para receber atendimento. Questiono então o segurança que me parece ser, portanto, o responsável pela não entrada do paciente, e este me diz: "hoje ele não vai ser atendido". Afinal, o homem continuou sentado do lado da porta de entrada, e cada vez que identificava alguém de branco chegando ou saindo, levantava e punha-se a pedir atendimento, sendo facilmente dispensado.

No pronto-socorro, os pacientes que, de uma maneira geral e consensual, são pouco levados a sério, objetos de desconsideração e de ironia, são os ditos 'drogados' e 'bêbados', as mulheres que chegam, gritando e/ou chorando, assim como os pacientes (homens ou mulheres) que apresentam urn estado de grande nervosismo. Importa assinalar que todos têm em comum serem considerados e designados como 'casos psiquiátricos'.

\section{As Recepcionistas}

Por preencherem as fichas dos pacientes que chegam no pronto-socorro, as recepcionistas desempenham um papel muito importante na triagem. Não receberam nenhuma formação na área médica e dizem geralmente ter aprendido seu trabalho uma vez na função, graças à ajuda de uma recepcionista mais experiente que lhes explicou como e o que fazer. "No início, você não sabe o que é, o que não é, fica que nem barata 
tonta!", lembra-se uma delas. São em três na recepção das $7 \mathrm{~h}$ às $19 \mathrm{~h}$. Depois desse horário, chegam outras três que ficam até as $23 \mathrm{~h}$, quando são substituídas por outras duas que trabalham até as $7 \mathrm{~h}$ da manhã. Se os seguranças e porteiros são todos homens, na recepção só trabalham mulheres.

No momento do preenchimento da ficha, as recepcionistas pedem várias informações ao paciente (ou a seu acompanhante). Primeiro, seus dados pessoais: nome, endereço, estado civil, nível de formação escolar. Elas também perguntam a religião para, segundo elas, "saber se a pessoa aceita ou não a transfusão. Assim, no caso de problema, o médico está protegido". Na ficha, a cor do paciente há de ser mencionada, mas para conseguir um dado de tão imediata visibilidade, as recepcionistas não precisam perguntar e os pacientes ignoram a anotação dessa característica. Depois, através de perguntas breves, como "consulta para quê?", "o que aconteceu?", "qual o problema?", elas obtêm as informações a partir das quais decidem que tipo de médico o paciente vai consultar (clínico geral ou especialistas) e também avaliam a urgência de seu problema, se ele deve ou não passar na frente de outros. São elas que colocam as fichas nas caixas reservadas aos médicos ${ }^{13} \mathrm{e}$, quando acham que um paciente não pode esperar, colocam sua ficha na frente das outras. Neste caso, acontece também delas chamarem a atenção de um médico ou, ainda, mandarem o paciente entrar direto nas áreas de atendimento.

Eu já sei quem vou levar lá [área de atendimento] e quem vai ficar na sala. You ver o médico na sala de emergência... Cólica de rim, sutura entra direto. É emergência por mais leve que seja.

Quando achamos que não é grave, que pode esperar, colocamos na caixa [da triagem clínica geral] para o médico ver e encaminhar: Qucundo achamos qué é grave, o coração, uma dor aqui [aponta o peito], colocamos a ficha dentro [da área de atendimento]. Assim, o médico já sabe. Para sutura também a fichá dentro.

Às vezes a gente se engana, mas, pelo que eles [os pacientes] disem, dápara saber.

Se for problema de menstruação é o ginecologista, se é uma dor Imostra a parte de cima do corpo] é o clínico geral.

As informações que as recepcionistas conseguem, oralmente, dos pacientes sobre seu problema são pouco numerosas, pois, como veremos mais adiante, eles geralmente respondem brevemente. No momento em que preenchem a ficha, elas se apóiam, também, em elementos de ordem visual e avaliam o estado dos pacientes em função do que elas observam e do que eles dizem. Por exemplo, quando uma mãe quer ser atendida logo, pois segundo ela, seu filho está com muita febre ou com corte na cabeça, elas pedem para dar uma olhada no nenê e, a partir do que decifram visualmente (a expressão no rosto da criança está ruim ou, ao contrário, parece boa), atendem o pedido da mãe - dizendo para ela entrar direto na área de atendimento infantil - ou não. A seleção, por especialidades e por grau de urgência, dos pacientes que passam pela recepção é feita em função da avaliação dessas funcionárias que, aliás, não se 
reconhecem em nenhum papel significativo na triagem. Interrogadas a esse respeito, dizem que a triagem começa antes delas, pelos seguranças, e que seu trabalho apenas consiste em "tentar saber o problema do paciente", para já ir encaminhando às respectivas especialidades.

A partir das perguntas que fazem, as recepcionistas revelam o que consideram (possivelmente) grave e urgente e quais são os sinais por elas levados a sério. Eis alguns exemplos de suas conversas com os pacientes no momento do preenchimento das fichas (excluída a parte relativa aos dados pessoais). Trata-se, aí, de pacientes atendidos em seguida pela mesma recepcionista.

P1 [Mulher, 70 anos]: - Tomei um banho, travou a coluna.

$\mathrm{R}$ :-Travou as costas?

P1:-Travou a coluna, dá uma dor!

P2 [Mulher grávida, 34 anos]: - Estou com dor.

$\mathrm{R}:-$ Quantos meses?

P2:- Vai fazer nove.

$\mathrm{R}:-$ Está perdendo líquido?

P2:- Não sei, está descendo alguma coisa.

R: - O que aconteceu com o nenê?

P3 [Um casal jovem para seu nenê de 7 meses]: - Está chorando dia e noite.

P4 [Homem, 46 anos]: - Quero passar pelo médico de rim, sei lá..

R:- Tem dor?

P4: - É isso.

$\mathrm{R}:-$ Começou quando a dor?

P4:- Ontem.

[Como pergunto para a recepcionista porque quer saber desde quando começou a dor, cla me responde:- Para passar para o médico se ela for forte e súbita. A dor dele dá para esperar mais um pouco].

P5 [Homem, 50 anos] :- Quero consultar um dermatologista, o que fazer?

R:- Tem que agendar.

P5: - Fazer o quê?

R: - Passar pelo posto de saúde e pedir encaminhamento.

$\mathrm{R}:-\mathrm{O}$ que que é?

P6 [Homem, para seu filho de 3 anos]: - Ele está com tosse seca. 
P7 [Mulher, 30 anos]:--Caí duma escada, quebrei dois dedos do pé, até agora não fiz nada.

R: - Há quanto tempo?

P7:- Uma semana.

[Ai, a recepcionista, em dúvida, pergunta para uma colega para qual especialista vai encaminhar a moça, e resolve mandar para o clínico geral. E me explica:-Até quatro, cinco dias, passo para a ortopedia, depois para o clínico geral].

$\mathrm{R}:-\mathrm{O}$ que aconteceu com ela?

P8 [Homem, para sua filha de 4 anos]: - Ela está vomitando, está com fébre. A febre eu contei. Sente tontura.

P9 [Homem para sua mulher]:-Ela tem problema no intestino. É muito ressecada. Onde que encontro um médico?

R:-Aqui é pronto-socorro, só se for grave. Se não, agenda pelo posto de saúde. Aqui quem vai atender é só clínico geral. Agende pelo posto de saúde, para ela ver um especialista.

[Depois da partida do homem, a recepcionista comenta para mim: - Eles não sabem, acham que PS é tudo, que pode resolver tudo].

R: - Para a senhora?

P10 [Mulher, 33 anos, nivel universitário, lendo na fila até ser atendida]: - Sim.

$\mathrm{R}:-\mathrm{O}$ que aconteceu?

P10: - Problema de cuvido, não estou ouvindo nada.

P11 [Mulher para sua mãe de 61 anos]: - Ela está ruim. Cheguei, estava fraca, cabeça fraca, desde dezembro que não come. Não pode ficar assim, filha! Não consegue tomar conta da casa dela.

$\mathrm{R}$ : - Vai consultar com o psiquiatra.

P11: - A minha mãe precisa. Ontem já veio e não foi atendida. Tinha pedido um clínico geral.

P12 [Homem, 36 anos]: -- Quero consultar de novo.

R:- O que é?

P12: - Acho que é rim.

P13 [Homem, 53 anos]: - Estou com mau jeito nas costas, carreguei peso.

R: - Quando?

P13: - De manhã.

R: - Está com dor de cabeça?

P13:- Não. 
P14 [Homem, para seu sobrinho]:-Meu sobrinho tem que internar, ele é muito ruim. $\mathrm{R}:-\mathrm{O}$ que tem?

P14: - Sabe... o que tem... como explicar... ele está muito ruim. O caso dele é grave, tem que atender já, que é muito grave.

R: - Tem um acidentado dentro, vai ter que esperar alguns minutinhos.

[Como, depois da partida do homem, pergunto para a recepcionista o que acha que tem o sobrinho, ela me responde: - Tem tudo!]

P15 [Mulher, para sua filha de 5 meses]:- Ela está ruim.

$\mathrm{R}:-\mathrm{O}$ que ela tem?

P15:-Está com febre, grita, chora.

R:-- O que ela tem?

P16 [Mulher, para sua filha de 6 meses]: - Muita febre.

PI7 [Homem, 40 anos]: - Quero consultar pro joelho.

R:- O que aconteceu?

P17: - Já fiz cirurgia, joguei...

R:- Bateu o joelho ou torceu?

P17: - Não, chutei.

R:- O que aconteceu com o senhor João?

P18 [Mulher, para seu marido levado pelos bombeiros]: - Começou inchar as pernas e depois caiu.

R:- O que aconteceu com ela?

P19 [Mulher, para a sua filha de 8 anos]: - Bateu a cabeça. Levei um susto.

$\mathrm{R}$ :- Estava brincando?

P19: - Não, estava descendo a rua. Bateu a cabeça numa caixa de táxi.

R: Cortou?

P19: - Não furou, sangrou bastante.

R:- Aguarde.

[Comentário da recepcionista para mim: - Minha mãe não me levava para essas besteiras!].

P7: A mulher com os dois dedos quebrados, [de volta na recepção, irritada porque ninguém a atendeu. Queixa-se de que foi dito para ela que o clínico geral ia atender, mas agora "uma mulher" acabou de dizer para ela que "é do ortopedista". Quer saber o que fazer e se vai esperar ainda muito, pois já esperou muito o clínico e se tiver que esperar isso tudo de novo para ver o ortopedista...] 
R:- Moça, o seu caso é do clínico geral. Ortopedia para nós é urgência, para nós o máximo é cinco dias.

P7:-- Se eu voltar amanhã, tem problema?

R: - Não.

P7 [indo embora]: - Não acredito, que saco!

[Comentário irritado da recepcionista depois da partida da moça:- Quebrou os dedos há duas semanas! Você acha que é urgência! Reação da recepcionista do lado: - Não é não. Se você passar para o orto, não vai gostar].

\section{Outro dia, outra recepcionista}

R: - Qual é o problema?

P20 [Mulher, para seu nenê que está chorando sem parar]: - Muita febre.

$\mathrm{R}$ :- O que que ele tem para chorar tanto?

P20: - Acho que é febre.

$\mathrm{R}:-$ Será que tem dor?

[O nenê vomita na frente da recepcionista].

Outra R do lado: - Por que chora tanto?

R: - Pode sentar com ele atrás, passa primeiro.

IChega o médico atuando na triagem infantil que vem buscar as fichas na recepção. A recepcionista que preencheu a ficha do nenê assinala o caso e seu caráter preocupante para o médico, dizendo: - chorando, chorando, chorando demais...].

P21 [Mulher para sua filha de 20 anos]: - É para consultar com o ginecologista.

Ela está grávida, está com dor.

$\mathrm{R}:-$ Quantos meses?

P21:- Sete meses. Será que vai demorar? Porque ela tem dor.

$\mathrm{R}:-\mathrm{Tem}$ que aguardar.

P22 [Homem, 62 anos]: - É só para medir a pressão. Sinto tonturas...

[O homem começa a tremer, segura-se ao balcão, parece muito mal.]

R: - Você vai passar pelo médico, pode aguardar nos bancos.

[Na fila, alguém pergunta alto se vai durar ainda muito tempo. A recepcionista diz que sim, que é assim para todo mundo. A pessoa então responde, também irritada: - Mas aqui é emergência. Por que demora tanto!?].

P23 [Mulher para a filha de 25 anos]: - Deu crises fortes, está com pé inchado.

R:- Crise de quê? Nervoso?

P23:-Sim. 
[Chega uma outra mulher, P24, que corta a conversa]:

P24:- Pode atender a menina que está passando mal?

R: - Foi o quê?

P24: - Acidente... Enquanto isso [o preenchimento da ficha], ninguém pode atendê-la?

[Chega uma outra mulher, P25]:

P25:- Será que vai demorar para atender, ela se sente muito mal.

R:- O que aconteceu com ele?

P26 [Mulher para seu filho de 8 anos]:- Ele tem o braço inchado.

R:- Caiu?

P26: - Não sei, se foi brincando... o que ele fez.

P27 [Mulher para seus dois filhos, 1 de um ano, o outro de 8 anos, brincando]:

[Como não pude ficar atenta à conversa entre as duas, pergunto à recepcionista 0 que a mãe disse que têm as crianças].

R:- Não sei, acho que nem perguntei... Geralmente é gripe, febre.

$\mathrm{R}$ : - Consulta para quê?

P28 [Uma mulher de 76 anos]: - Porque eu tenho muita dor no peito e nas costas, do lado esquerdo [ela mostra seu lado esquerdo].

$\mathrm{R}$ : - Não é porque a senhora carregou algum peso?

P28:- Não.

[Uma vez a mulher tendo ido embora, a recepcionista pergunta para uma de suas colegas : "-É a gripe, nâo é ?", e encaminha a ficha para o clínico geral].

P29 [Mulher para sua mãe de 62 anos]: - A minha mãe está passando mal, tem pressão alta.

R:- Você mediu?

P29:- Sim, na farmácia.

R:- Quanto?

P29: - 15 e 8 acho.

R: - Ela toma uma medicação?

P29:- Não.

R: - Não?

P29:-É a primeira vez.

$\mathrm{R}:-$ A primeira vez? Aguarde, que ela vai ser atendida.

[ $\Lambda$ recepcionista vai falar com um médico e a paciente é atendida em seguida]. 
$\mathrm{R}:-\mathrm{O}$ que aconteceu?

P30 [Homem, 25 anos]: - Ontem, voltando do serviço, uma mulher louca bateu em mim, fugiu, bateu no meu ombro e quebrou dois dentes.

$\mathrm{R}$ : [para outra recepcionista]:- Tem que fazer ocorrência?

Outra R: - Ontem, não!

P31 [Mulher, 27 anos]: - Aquele médico gordão, é ele que atende?

R:-Que gordão?

P31:- Ontem eu vim, é ele que me atendeu.

R: - O que foi?

P31:- Inflamação dum canal de urina.

[Comentário da recepcionista depois da partida da paciente: - Você acha que é jeito de falar! Gordão!].

R: - Fala, bem!

P32 [Mulher para sua filha de 5 anos]: - Uma consulta para ela.

$\mathrm{R}$ :- O que aconteceu?

P32: - Está com febre, com gripe, está vomitando.

P33 [Homem para sua irmã de 53 anos]: - Vou explicar, sou de Assis, o médico não acha o que ela tem, então vim aqui.

$\mathrm{R}:-\mathrm{O}$ que ela tem?

P33: - Desmaia, já três vezes.

R: - O que ela tem hoje?

P33: - Dor no peito e desmaia... Trabalha, mas já não agüenta trabalhar... empregada.

P34 [Mulher, para seu nenê de 1 ano]:

$\mathrm{R}:-\mathrm{O}$ que aconteceu?

P34: - Passou o dia sem gosto.

$\mathrm{R}:-\mathrm{O}$ que aconteceu [com o nenê], bem?

P35 [Casal, o pai e o nenê de um ano]:-O médico pediu para fazer raio-X... Eu vou tomar injeção.

R:- De quê?

P35:-De Wycillin

R: - Só aguardar.

P35:- Só aguardar?

R: - Só aguardar... A receita é de onde moço? 
P35:- Como?

$\mathrm{R}:-\mathrm{Da}$ onde que é esse encaminhamento?

P35: - Do posto $\mathrm{X}$.

R:- Eles não costumam fazer mais... Com receita de médico particular não pode mais. Você tem que ir para a Santa Casa.

[Comentário da recepcionista depois do casal ter ido embora quieto: - Milagre, ele aceitou. É raro!]

$(\mathrm{P}=$ paciente ou acompanhante; $\mathrm{R}=$ recepcionista $)$

Como se pode constatar, as interações entre pacientes, acompanhantes e recepcionistas são bastante breves. No que diz respeito à identificação do problema do paciente, o diálogo se resume, geralmente, a uma ou duas perguntas e respostas. Portanto, é suficiente para as recepcionistas efetuarem a triagem. Suas perguntas são sucintas e precisas e as falas dos pacientes, gerais e sumárias, são pobres do ponto de vista descritivo: "estou passando mal", "está ruim", "estou com dor".

Quando as recepcionistas obtêm informações orais e/ou visuais que as levam a suspeitar de algum problema sério, geralmente insistem em saber mais sobre os sintomas do paciente e sua situação de saúde, assim como mostram os exemplos P2, P4, P13, P19, P20, P2 1, P28, P29. Procuram tirar ou confirmar suas dúvidas. Muito atentas, por exemplo, aos sinais que parecem com um início de parto ou de aborto e com os sintomas de enfarte e derrame, mostram-se atentas às pacientes grávidas que estão com dor e interrogam mais os pacientes que se queixam de pressão alta ou baixa, de dor no peito, de dor do lado esquerdo ou no braço esquerdo. O mesmo acontece com os pacientes que dizem ter alguma coisa quebrada, pois, segundo suas instruções, "na ortopedia tudo é urgência, porque não se sabe se for fratura". ${ }^{14}$ De qualquer maneira, "se tiver uma urgência na gineco ou na orto, passa primeiro".

$\mathrm{O}$ que é urgente para as recepcionistas (que aliás usam muito pouco o termo emergência ${ }^{15}$ ) é "o que não pode esperar". Essa equivalência também existe para elas e, conforme as representações dos próprios médicos, "o que pode esperar" é tudo que não é repentino nem muito forte. Daí as perguntas "desde quando?", "há quanto tempo?", "faz tempo?", "é a primeira vez?", que fazem em relação à dor, ao problema, ao membro quebrado, cujo paciente se queixa (P4, P7, P13, P33). A partir do momento em que o problema não é de agora, "dá para esperar mais um pouco", como elas mesmo dizem. E, de fato, por decisão das recepcionistas, os pacientes que sofrem de problemas que passam do "hoje" tendem a ficar mais tempo na espera.

A atenção seletiva que manifestam para a possível gravidade de certos sinais é o resultado, de um lado, das indicações e instruções que recebem por parte dos médicos e de sua experiência profissional. Mas, de um outro lado, ela também está ligada ao que toca sua sensibilidade ${ }^{16} \mathrm{e}$, aí, a avaliação escapa nitidamente do registro estritamente médico e pode provocar o descontentamento dos médicos. Aparece claramente na maneira como triam as crianças, e especialmente os nenês, em relação aos outros pacientes: procuram facilitar e acelerar sua entrada na área de atendimento infantil. Aí, ao contrário 
do que acontece com os adultos, certos sinais, quando manifestados pelos nenês, se tornam preocupantes na medida em que existem desde tempo. É o caso, particularmente, do choro. Assim, uma criancinha que não pára de chorar na fila e, depois, na espera, assim como um nenê cujos pais dizem que chora sem parar, desde dias e noites, mobiliza a atenção das recepcionistas e tende a passar na frente dos outros (P20). "Criança, eu tenho dó", dizem umas; "criança, nunca se sabe o que tem", dizem outras. Por isso, liberam com freqüência sua entrada na área de atendimento, com ou sem o acordo prévio dos médicos. Várias vezes, notei a irritação de pediatras em relação a esse comportamento, pois, segundo eles, as recepcionistas mandam os pais com as crianças direto para a área de atendimento para coisas sem importância:"A mãe fala em intoxicação, e a recepcionista leva ao pé da letra e manda direto a criança para o bloco. Ela não olha a criança, elas ficam na queixa da mãe, do pai. Não batem o olho para dar uma olhada na criança!" [Fala de um pediatra expressando sua exasperação a uma enfermeira].

Essa crítica comum mostra que os médicos esperam que as recepcionistas, não só preencham a ficha dos pacientes, mas também atuem na triagem, e isso de maneira certa e eficiente.

Um outro exemplo de que a percepção da urgência não reside só nos sinais que dizem respeito, estritamente, ao problema de saúde e à queixa dos pacientes, são as reações das recepcionistas em relação às pessoas cuja aparência (maneira de ser, de falar, indumentária) revela que pertencem a uma camada social elevada. As interações com esse tipo de pacientes, raros no pronto-socorro, perturbam-nas. Com eles, mostram-se menos diretivas, secas e seguras de $\mathrm{si}$ - tanto no tom de suas perguntas quanto no comportamento geral - do que com os numerosos pacientes de aparência modesta ou miserável. "Quem é bem vestido, tem aparência boa, assusta as recepcionistas que colocam a ficha na frente. O cara passa na frente", comentou comigo um médico do pronto-socorro, confirmando assim minhas observações. $\mathrm{E}$, de fato, esses pacientes nunca ficam por muito tempo na espera. Mas essa realidade não é só devida à solicitude das recepcionistas. Apesar de o médico anteriormente citado acrescentar em seguida: "não aceito, eu olho o horário de chegada nas fichas e respeito a ordem de chegada", ela é o resultado de um consenso geral. No pronto-socorro, independente da natureza de seus problemas e queixas, os pacientes que têm uma 'aparência boa' parecem emergências em si mesmos: eles não podem esperar.

De maneira geral, as recepcionistas são bastante críticas com os usuários, principalmente no que diz respeito ao comportamento (o fato de eles irem ao pronto-socorro em vez do posto de saúde; sua falta de paciência) e ao entendimento (ou melhor, na visão delas, o não entendimento) do que é urgente: "O que eles [os pacientes] têm geralmente não é urgente, não é grave. Atrapalha o trabalho, se chegar uma emergência, estão todos ocupados [os médicos]. Têm que deixar o que eles estão fazendo para atender"; "Olho de peixe, não é urgência. Pode esperar". [Olhando para sua colega, e vendo a expressão duvidosa do rosto dela, a recepcionista acrescenta]: "a não ser inflamado"; "Eu pergunto à pessoa porque ela não vai para o posto de saúde. Ela responde sempre: - porque não tem médicos". "Todo mundo quer ser atendido com urgência. Não tem paciência". 
Elas também julgam negativamente o próprio pronto-socorro. Mas não como os seguranças que denunciam, sobretudo, o comportamento dos profissionais da saúde em relação aos pacientes: o desrespeito, a falta de atenção, de cuidados. O que elas criticam, sobretudo, é a inadequação entre sua função declarada - só atende urgência/ emergência - e sua função real, que, para elas, é de ordem ambulatorial: "A maioria [dos pacientes] é posto de saúde. Tem pessoas que procuram o PS para unha encravada!";17 "Acho que aqui não é PS. Todo mundo espera aqui. Tem consultas. Acho errado. Deveria ter um ambulatório ${ }^{18}$ e um PS"; "A obstetrícia no PS teoricamente é só urgência, mas geralmente não é."

Enfim, as recepcionistas lamentam bastante o desconfortável papel de bode expiatório que são levadas a desempenhar no pronto-socorro. ${ }^{19}$ Em contato direto com os usuários, enfrentam seus comentários negativos, suas irritações, suplicações e queixas pèla demora, sua pressão para obter um atendimento. Aliás, a presença de uma grade de separação na recepção impõe uma distância e limites físicos entre elas e os pacientes: visa a evitar que o contato, apesar de direto, esteja demais próximo ou se torne confronto. Além disso, as recepcionistas são os emissários de instruções e decisões dos médicos ou da direção do hospital, que desagradam os pacientes. Como aplicam-nas, dão a impressão de estar na sua origem. Vivem mal esse mal-entendido e as conseqüentes reações dos usuários descontentes ou indignados: "Acho errado, não é a gente que deveria despedir, deveria ser alguém da enfermagem. Depois as pessoas acham que nós decidimos, que não queremos fazer a ficha". [Comentário de uma recepcionista depois de ter-se recusado a fazer a ficha de um paciente que queria ser atendido. Portador de uma receita feita por um médico particular, não podia fazer no pronto-socorro o exame nela indicado].

Mas nem sempre assumem o papel de bode expiatório esperado delas. Em certas ocasiões até se negam a desempenhá-lo, como no exemplo seguinte que mostra a reação à instrução dada por um médico que pediu para avisar as mulheres grávidas, em trabalho de parto, que não podiam ser atendidas no pronto-socorro. Eis a fala dele para as recepcionistas: "Queridas, não tem mais leito, não pode nascer mais nenê hoje neste hospital. Podemos atender, mas não dá para fazer parto nem internar. Estamos sem leito. Avisem as pacientes e, no caso de parto, encaminhem elas para o São Francisco. A não ser elas chegarem com a cabeça do nenê entre as pernas e que só tenha que puxar!". Uma vez o médico tendo ido embora, uma das recepcionistas, aprovada pelas outras, comentou: "Não vou dizer nada [às pacientes], não adianta nada. Imagina, ela vai embora e tem o nenê, lá na saída! Não gostaria de ficar no lugar delas! Imagina o desespero! É ele que vai encaminhar. Eu tenho que fazer a ficha, mas não posso encaminhar!". 


\section{NoThS}

1 Trabalham $12 \mathrm{~h}$ por dia, um dia sim, um dia não (todos os dias pares ou ímpares), das $7 \mathrm{~h}$ às $19 \mathrm{~h}$ para a equipe diurna, com um único intervalo de vinte minutos às $11 \mathrm{~h}$ para almoçar.

2 Ver, em anexo, o mapa do pronto-socorro.

3 No que diz respeito à sala de espera infantil, ninguém vê o que acontece nela. Na configuração física do pronto-socorro, ela ocupa um cantinho escondido no fundo que não dá para ser visto do lugar onde se encontram os seguranças e porteiros e, aliás, de nenhum outro lugar.

4 O mais antigo do qual se tratou anteriormente.

5 Trecho relativo ao caso de uma paciente jovem que chegou com uma amiga e uma criança. Ficou sentada enquanto a amiga foi preencher sua ficha. Ficaram aguardando algum tempo, quando a acompanhante de repente levantou e foi conversar com o segurança. Em seguida, este levou a paciente para a área de atendimento médico onde foi atendida imediatamente. $O$ feto, transportado depois pela equipe médica correndo, da área de atendimento adulto para a área de atendimento infantil, não sobreviveu.

6 Apesar de mostrarem-se sensibilizados pelos pacientes que sofrem, os seguranças deixam geralmente na espera os que se queixam de dores musculares, 'nas costas', 'na perna', 'na coluna'... Esses podem (têm que) esperar, mesmo se "é duro".

7 Contando com sua capacidade e perspicácia em reconhecer quem está mal de quem está bem; contando com eles para serem avisados da presença de pacientes que estão ruins.

8 Como, por exemplo, ir ao pronto-socorro, voltando de uma festa à noite, quando não há mais ônibus, para beneficiar-se de uma ambulância para voltar para casa; obter um atestado médico porque faltou no serviço etc.

9 Bem diferente dos comentários do porteiro sobre o 'passei mal' dos pacientes, é essa explicação dada por um segurança a quem perguntei o que significava a expressão 'passar mal': "a pessoa quer dizer que alguma coisa aconteceu com ela".

10 Mais numerosos do que os "drogados" a virem ou serem levados ao pronto-socorro.

11 É como se não existissem apesar de suas manifestações, às vezes, gritantes.

12 É o caso, também, de homens não alcoolizados que chegam em estado de grande agitação.

13 O caminho seguido por essas fichas mereceria, em si, uma observação aprofundada. Teoricamente, é a ordem de chegada que prevalece na ordenação das fichas e, por consequêencia, na chamada dos pacientes. Mas a observação revela que há fichas que desaparecem ou que não são encaminhadas para os médicos (o que não é raro, o paciente ficando assim esquecido); há fichas de pacientes que chegaram há pouco na frente de outros que chegaram bem antes, isso sem que os primeiros estejam 
padecendo de um problema considerado mais urgente (a "teórica" ordem de chamada virando uma ordem sem muita ordem). Há também momentos em que a sala de espera está cheia e, entretanto, não há nenhuma ficha nas caixas dos médicos, mas também elas não estão com eles, nem com os enfermeiros. As fichas seguem percursos escuros que sublinham a necessidade de uma investigação requintada do que acontece com elas. É claro que o desaparecimento ou o não encaminhamento de fichas tem conseqüências na triagem, pois os pacientes cuja ficha não está entregue para o médico esperam muito. Foi o caso, por exemplo, de uma paciente grávida de 8 meses, acompanhada pelo marido, que, depois de duas horas e meia de espera, foi saber o motivo da demora. "Fomos informados", contou o marido, de que a recepcionista havia "esquecido" de encaminhar a ficha. Após a reclamação, a mulher foi prontamente chamada.

Segundo as instruções, é da competência da ortopedia se o paciente consultar no prazo máximo de cinco dias depois do acidente. Depois passa a ser da clínica geral.

15 As poucas vezes que as escutei usarem espontaneamente da palavra 'emergência' foi para designar pacientes acidentados.

16 Como, aliás, é o caso de todos os agentes - médicos e não médicos - que atuam na urgência/emergência (fora e dentro do pronto-socorro).

17 A unha encravada é muito utilizada pelo pessoal do pronto-socorro (médicos incluídos) como o exemplo, por excelência, de problema não urgente, de recurso não justificado ao pronto-socorro.

18 Já há um ambulatório no próprio hospital. Quando a recepcionista fala em 'ambulatório' e PS, ela quer dizer um serviço de pronto-atendimento de tipo ambulatorial para tudo que não é urgente e um pronto-socorro somente para as urgências/ emergências.

Que os seguranças e porteiros também desempenham num grau menor. 